POLSKA AKADEMIA NAUK - ZAKEAD BADANIA SSAKOW
A $C$ C $\mathrm{T}$ A
T

VOL. VI, 8.

BIAEOWIEŹA

20.X.1962

Ryszard H A I T.L I N G E R

\title{
Morphological Variability in Apodemus agrarius (Pallas 1771)
}

\section{Zmienność moriologiczna Apodemus agrarius (P a llas 1771)}

\section{[With 8 Tables, 4 Figs., and Plates LIII-LIV]}

I. Introduction

II. Method of investigation . . . . 240

III. Age structure of the population . $\quad . \quad 241$

IV. Dimensions and weight of body . . . 244

V. Craniometrical measurements . . . . . . . . . . . . 246

VI. Indices . . . . . . . . . 250

VII. Sex ratio . . . . . . . . . . . . 251

VIII. Sexual dimorphism . . . . . . . . . . . . . 252

IX. Results . . . . . . . . . . . 254

References . . . . . . . . . . 254

Streszczenie . . . . . . . . . . . . . . 255

\section{INTRODUCTION}

Literature concerning the field mouse is relatively scarce in Poland and in foreign countries. It is principally concentrated around a problem of bioecological and faunistic character. There is a rather striking lack of a greater amount of data concerning this species, which is very common in the area where it is found and can be caught quite easily. The terrain inhabited by the field mouse is extremely large while its differentiation in colouring and morphological traits is small; it is composed of several subspecies not greatly differing from each other (A rgy rop ul o, 1940; E 1le r m a n, 1949). Disposing of a relatively large material differentiated as to age and collected in all seasons, I determined to analyse the morphological changes from the individual and seasonal point of view as well as that of age. 


\section{METHOD OF INVESTIGATION}

Apodemus agrarius ( $\mathrm{P}$ a 11 a s 1771) specimens were caught in one of the suburbs of Wroclaw, Siedlec, in a rubble-covered terrain and also in the vicinity of Opatowice in the years 1959-1961. The material was measured and weighed before preparation and kept in the shape of skulls and pelts. The entire material is included in the collection of the Chair of Zoology in the High School of Agriculture in Wroclaw. Among the 544 individuals not all skulls are undamaged and permitting measurement.

The skulls were measured under a measuring microscope. The height of the brain-case was measured by means of a vernier calipers, and its capacity was determined by filling the brain-case with quick-silver (P u cek, 1955).

The material was divided into 5 age groups on the basis of the degre of abrasion of the teeth.

Group I - young specimens. They were practically caught immediately after leaving the nest. Their $\mathrm{M}^{1}$ and $\mathrm{M}^{2}$ are well developed, with no trace of abrasion. $\mathrm{M}^{3}$ is not yet cut and is situated deeply in the tooth-socket. Dentition of that type is shown on Phot. 1, Plate LIII.

Group II $-\mathrm{M}^{3}$ is already well developed. The two remaining molars have cusps with no or only faintly marked traces of abrasion, the loops being usually closed. Strongly- differentiated individuals belong to this group, fluctuations in weight and length of separate elements of the body are considerable, this being caused by the process of growth, very rapid at that time. The period of independent life does not transgress 1 month (Phot. 2).

Group III - the cusps of all molars are visibly abrased and the intercusp spaces are broad. $\mathrm{M}^{1}$ is the least worn, $\mathrm{M}^{2}$ and $\mathrm{M}^{3}$ much more so being often deprived of cusps. On specimens of this group the process of a more rapid abrasion of $\mathrm{M}^{3}$ than of the remaining molars is clearly seen. This was also observed by A da m c z e w$\mathrm{ska}(1959)$ in Apodemus flavicollis ( $\mathrm{Mel} \mathrm{ch}$ i or 1834). Their age is of $2-5$ months (Phot. 3).

Group IV - $\mathrm{M}^{3}$ deprived of cusps, very deep abrasion, $\mathrm{M}^{2}$ with slightly marked cusps. They are expressed in the strongest manner in $\mathrm{M}^{1}$. Age: 5-10 months (Phot. 4).

Group V - the specimens qualified here have a completely abrased dentition. Age: above 10 months (Phot. 5, Plate LII).

As has been often indicated ( $\mathrm{K} \mathrm{u} \mathrm{bik,} \mathrm{1952;} \mathrm{W} \mathrm{a} \mathrm{silewski,} \mathrm{195 \% )} \mathrm{there} \mathrm{are} \mathrm{no}$ distinctly marked delimitations between separate groups. Individuals with indistinctly marked traits of a separate group must obviously be considered as belonging in the opinion of the investigator to one of the age classes. Features that are often considered in division into size groups, such as the weight, the length of the body or the condylobasal length, depend however in a still greater measure on developmental factors and on life conditions than the state of the dentition; they are therefore incomparably less useful. M e i e $\mathrm{r}$ (1957) states that the differences in the mean figures for weight in Citellus pygmaeus (P a $11 \mathrm{a}$ s) individuals of the same age, but from different terrains, amounted to $18 \mathrm{~g}$. Similarly in the voles a loss of $50 \%$ of body weight can occur in the course of a month, especially in conditions of insufficient moisture of food. Moreover, notwithstanding the method that is being used, all measurements are burdened by the subjective standpoint of the author. Identical measurement points are often impossible to consider, and, in effect, the results obtained cannot be compared. That is why I calculated a series of indices which can provide a more objective material for comparison. 
Table 1 and Fig. 1 present the number of individuals captured in separate months (in a group disposition) and seasonal changes in the structure of a population. Summarical results cannot be fully compared with each other owing to the different intensity of capturing in successive months. They only present approximatively data concerning numerical relations of individuals of a different age in their seasonal aspect. Numerical proportions in different months, however, are fully comparable and represent distinctly the course of the process of a cyclic structural change in the population. The month of June is the first month of the year in which an age differentiation of a population of mice takes place in a visible manner. This is the result of the appearance of young individuals from early spring litters (in favourable circumstances they can already be seen in the be-

Table 1.

General list of captured individuals of both sexes.

\begin{tabular}{|c|c|c|c|c|c|c|c|c|c|c|c|c|c|c|}
\hline Age group & Sex & I & II & III & IV & $\mathrm{V}$ & $\begin{array}{l}0 \mathrm{n} \\
\mathrm{VI}\end{array}$ & $\begin{array}{l}\text { bs } \\
\text { VII }\end{array}$ & VIII & IX & $x$ & $X I$ & XII & Total \\
\hline I & $\frac{99}{66}$ & & & & & & - & $\begin{array}{l}3 \\
2\end{array}$ & - & $\begin{array}{l}3 \\
1\end{array}$ & $\begin{array}{l}2 \\
3\end{array}$ & & & $\begin{array}{l}8 \\
8\end{array}$ \\
\hline II & $\begin{array}{l}q 9 \\
66\end{array}$ & & & & & $\begin{array}{l}2 \\
1\end{array}$ & $\begin{array}{l}2 \\
6\end{array}$ & $\begin{array}{l}2 \\
3\end{array}$ & - & $\begin{array}{l}17 \\
15\end{array}$ & $\begin{array}{l}31 \\
14\end{array}$ & $\begin{array}{l}1 \\
4\end{array}$ & & $\begin{array}{l}55 \\
48\end{array}$ \\
\hline III & $\begin{array}{l}+9 \\
\text { dó }\end{array}$ & $\begin{array}{l}8 \\
5\end{array}$ & $\begin{array}{l}1 \\
-\end{array}$ & & & & - & $\begin{array}{l}- \\
2\end{array}$ & $\begin{array}{l}4 \\
1\end{array}$ & $\begin{array}{r}4 \\
16\end{array}$ & $\begin{array}{l}33 \\
28\end{array}$ & $\begin{array}{l}40 \\
40\end{array}$ & $\begin{array}{l}22 \\
27\end{array}$ & $\begin{array}{l}112 \\
122\end{array}$ \\
\hline IV & $\begin{array}{l}\text { fo } \\
60\end{array}$ & $\begin{array}{l}2 \\
5\end{array}$ & $\begin{array}{r}6 \\
17\end{array}$ & $\begin{array}{l}11 \\
19\end{array}$ & $\begin{array}{l}2 \\
5\end{array}$ & $\begin{array}{l}2 \\
5\end{array}$ & $\begin{array}{l}2 \\
3\end{array}$ & $\begin{array}{l}2 \\
2\end{array}$ & $\begin{array}{l}1 \\
6\end{array}$ & $\begin{array}{l}4 \\
5\end{array}$ & $\begin{array}{l}9 \\
2\end{array}$ & $\begin{array}{l}2 \\
4\end{array}$ & $\begin{array}{r}2 \\
10\end{array}$ & $\begin{array}{l}45 \\
83\end{array}$ \\
\hline v & $\begin{array}{l}\text { fo } \\
\text { ofd }\end{array}$ & & 1 & 1 & $\begin{array}{l}2 \\
6\end{array}$ & $\begin{array}{r}8 \\
18\end{array}$ & $\begin{array}{l}1 \\
6\end{array}$ & $\begin{array}{l}1 \\
8\end{array}$ & & $\begin{array}{l}2 \\
2\end{array}$ & 4 & 2 & 1 & $\begin{array}{l}22 \\
41\end{array}$ \\
\hline Total & $\begin{array}{l}q q \\
06\end{array}$ & $\begin{array}{l}10 \\
10\end{array}$ & $\begin{array}{r}8 \\
17\end{array}$ & $\begin{array}{l}11 \\
20\end{array}$ & $\begin{array}{r}4 \\
11\end{array}$ & $\begin{array}{l}12 \\
24\end{array}$ & $\begin{array}{r}5 \\
20\end{array}$ & $\begin{array}{r}8 \\
17\end{array}$ & $\begin{array}{r}5 \\
12\end{array}$ & $\begin{array}{l}30 \\
39\end{array}$ & $\begin{array}{l}79 \\
47\end{array}$ & $\begin{array}{l}45 \\
48\end{array}$ & $\begin{array}{l}25 \\
37\end{array}$ & $\begin{array}{l}242 \\
302\end{array}$ \\
\hline
\end{tabular}

ginning of May). The majority of caught specimens are composed of wintering ones, mostly originating from the first spring broods of the preceding year. Later, a visible tendency of numerical lowering in the amount of old individuals and a constant increase in the number of young ones can be observed. This state of things lasts until August. Considerable changes, however, occur in the month of September, when more than $80 \%$ of the population consist of young individuals this being in relation with the natural death of these ones, which have lived through a winter. In the first phase of October the last young from September litters were caught, and on the whole from November onwards we only have individuals over 
two months old. May is the month when the greatest number of individuls belonging to the oldest group are caught. In later months, in relation to natural losses, their number greatly diminishes. In winter specimens with a completely abrased dentition are rarely seen. Field mice with a wholly abrased dentition form a strikingly low percentage of the entire material (slightly above $10 \%$ ). S te in (1938) in his investigations noted a similar state of things.

S viride n ko (1948) (after K r a to c hvil \& R os ick y, 1954) states that a field mouse in conditions prevailing in the U.S.R.R. attains the age of 3 years. This is not confirmed by my own observations. If such

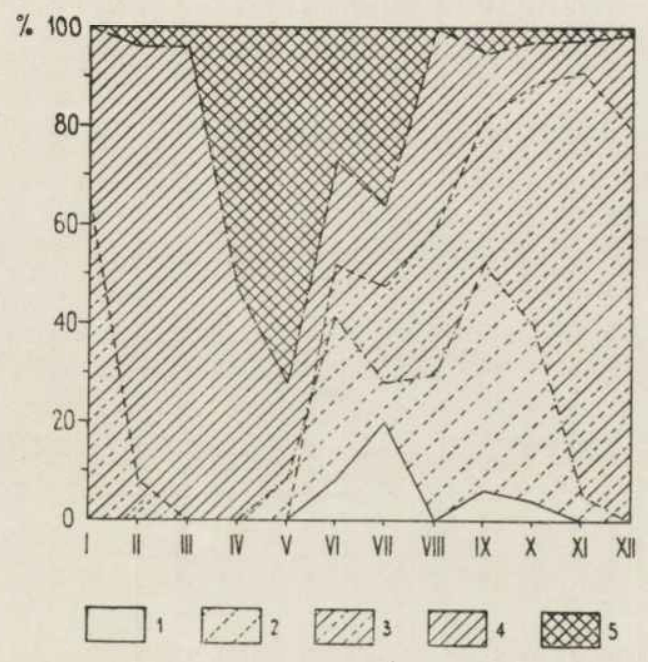

Fig. 1. Alterations in age composition of the population (in $\% \%$ )

1 - Individuals of age group I, 2-age group II, 3 - age group III, 4 - age group IV, 5 - age group $\mathrm{V}$.

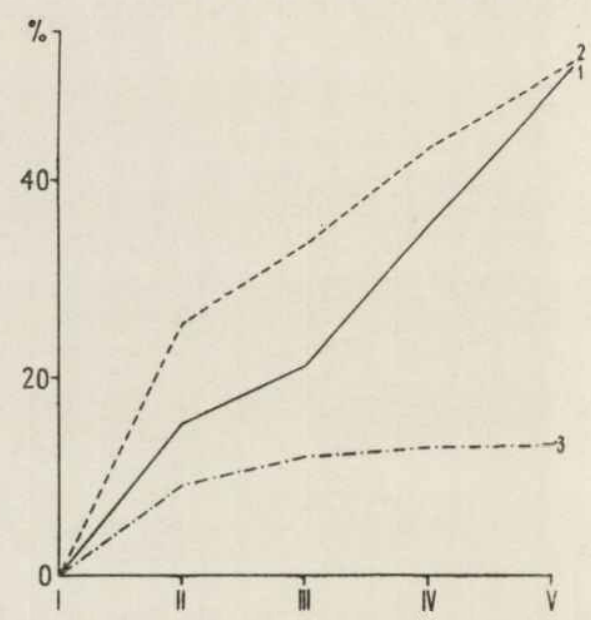

Fig. 2. Percentage of accretion in length of body, tail and foot in separate age groups.

$$
1 \text { - Head and body, } 2 \text { - Tail. }
$$$$
3 \text { - Hind foot. }
$$

a fact took place in the investigated terrain, the numerical relation of mice with entirely abrased teeth and of individuals with smaller abrasions ought to be more or less constant during the whole winter and spring season. Three specimens of group $\mathrm{V}$ caught during the winter season, in considerable absolute capturing, demonstrate that a similar opinion is unfounded. Practically, the life span of animals of this species is not longer than $1^{1 / 2}$ year. They live much longer in laboratory conditions, owing to completely different possibilities of living. 


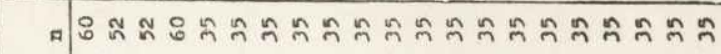

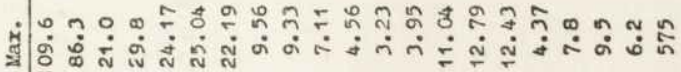

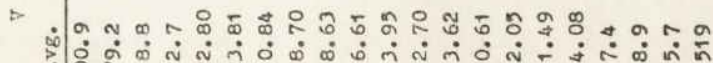
ठั่ ปี่

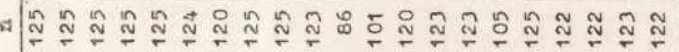

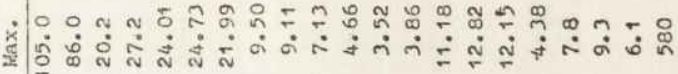
学

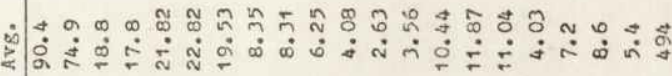

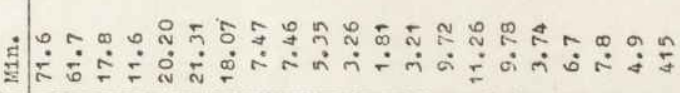

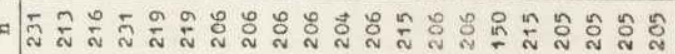

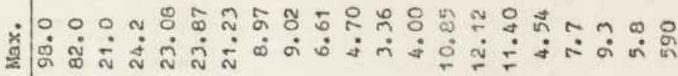
莺

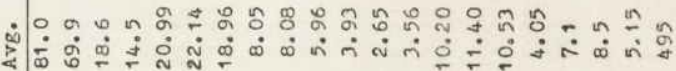

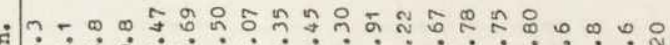

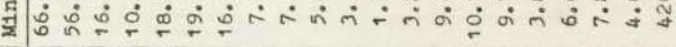

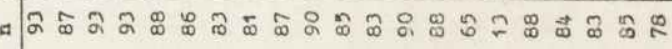

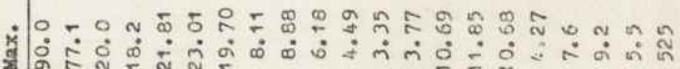

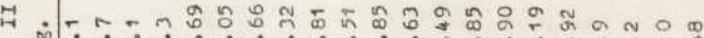

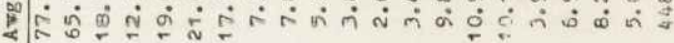

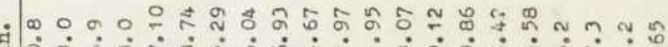

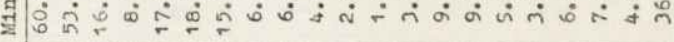

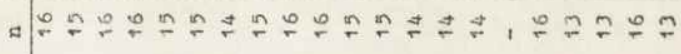

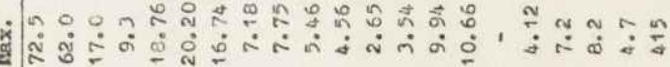
H - 0 웅ํำ

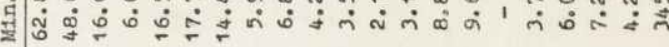

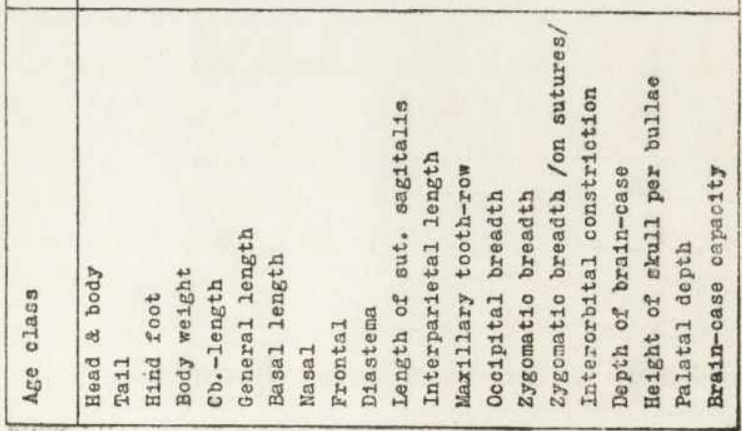




$$
\text { ? }
$$




\section{DIMENSIONS AND WEIGHT OF THE BODY}

The length of the body is one of the elements which are subject to the greatest changes in the process of growth of field mice (Table 2). In young specimens of group I individual differences in dimensions were considerable and fluctuated in the limits of $62.8-72.5 \mathrm{~mm}$. The process of growth of the body-length has no regular course as the age of the mouse increases. It is inhibited in certain periods and becomes more rapid in others. Acceleration of growth is especially visible between the 1st and 2nd group and between the $3 \mathrm{rd}$ and 4 th one - while between the 2nd and 3rd group inhibition takes place (Fig. 2). Individuals from early litters develop in favourable conditions, attain relatively rapidly the growth and size of adult individuals and take part in reproductive activities. The greater part of animals from later litters develop very rapidly in their 1st month

Table 3.

Seasonal variability of length of body and tail and of weight.

\begin{tabular}{|c|c|c|c|c|c|c|c|c|c|c|c|c|c|}
\hline & Age & I & II & III & IV & v & $\begin{array}{c}M \circ \mathrm{n} \\
\mathrm{VI}\end{array}$ & $\begin{array}{l}\mathrm{h} s \\
\mathrm{VII}\end{array}$ & VIII & IX & $x$ & XI & XII \\
\hline \multirow{4}{*}{ 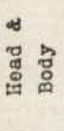 } & II & & & & & 87.0 & 92.1 & 79.9 & 78.8 & 76.4 & 76.0 & 77.4 & \\
\hline & III & 81.3 & 71.5 & & & & 100.3 & 96.5 & 83.3 & 84.0 & 80.7 & 80.4 & 80.8 \\
\hline & IV & 84.7 & 86.0 & 89.4 & 92.2 & 96.7 & 97.7 & 97.5 & 92.1 & 95.6 & 90.5 & 88.4 & 86.9 \\
\hline & v & & 86.0 & 102.7 & 101.0 & 97.7 & 96.4 & 103.7 & & 102.8 & 99.5 & 89.8 & 97.0 \\
\hline \multirow{4}{*}{ స్ } & II & & & & & 68.5 & 69.2 & 61.6 & 67.2 & 65.4 & 68.8 & 68.5 & \\
\hline & III & 70.3 & 62.8 & & & & 73.3 & 74.3 & 74.5 & 72.0 & 69.6 & 69.6 & 69.6 \\
\hline & IV & 69.9 & 71.3 & 72.9 & 77.9 & 74.3 & 79.0 & 72.3 & 77.1 & 77.7 & 78.0 & 75.2 & 73.3 \\
\hline & v & & 73.8 & 80.0 & & 79.4 & 78.8 & 79.8 & & 79.5 & 79.4 & 76.5 & 82.0 \\
\hline \multirow{4}{*}{ 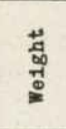 } & II & & & & & 15.6 & 17.5 & 12.1 & 13.9 & 12.7 & 11.8 & 12.5 & \\
\hline & III & 13.4 & 11.2 & & & & 20.5 & 17.1 & 18.4 & 16.6 & 14.1 & 14.2 & 13.7 \\
\hline & IV & 13.8 & 14.8 & 17.7 & 18.7 & 16.5 & 21.2 & 20.2 & 21.4 & 22.4 & 20.4 & 18.8 & 15.5 \\
\hline & v & & 19.5 & 22.5 & 21.8 & 22.6 & 23.7 & 22.9 & & 26.9 & 21.8 & 17.7 & 19.0 \\
\hline
\end{tabular}

of active life in the terrain, but this rate of growth is much slower in the following months. This is the autumn period and it is not favourable for further intensive development (Table 3) which is arrested during a long period (October-January). It is only in February that a considerably accretion of length takes place (the period of passing from age group III to group IV) and lasts until the end of summer. It is characteristic, however, that in rodents the process of growth is not inhibited with age but lasts nearly up to the end of their life. This is undoubtedly due to the short life of these animals which have no time to attain a period of stabilisation.

Marked differences in the dimensions of adult animals (class V, 81.3$109 \mathrm{~mm}$.) are perhaps connected with their life in different, often unfa.. 
vourable environmental conditions (B orowski \& Dehnel, 1952; K u bi k, 1952).

The increase in the length of the tail is most interesting. This increase is extremely rapid (Fig. 2) in young individuals (group II), but in older mice the rate is much slower and does not attain $10 \%$. Correlation with the length of the body appears distinctly in mice of the three first groups $\left(r_{x y}=0.692\right)$. In the oldest animals this correlation is considerably lower $\left(r_{x y}=0.492\right)$. It is interesting to note that the percentage relation of the length of the tail to the length of the body is the same in the youngest and in the oldest mice $-78.5 \%$ (in nearly adult mice in relation to the difference of intensity, already noted, in the accretion of the length of body and tail, this percentage is still higher). These data are not in accordance with those presented by S k u r a tow i c z (1948) and V in ogradov \& Gromov (1952) which determine this relation as being equal to $70 \%$. The accretion of the tail is inhibited in the autumn and winter months. For individuals of group III the mean figures for October, November and December are of $69.6 \mathrm{~mm}$. Greater accretion takes place in February.

In young individuals longer tails can be usually noted in bigger animals, and shorter tails in the smaller ones. In specimens which have lived through a winter (group IV) these lengths fluctuate usually in the limits of $71-80 \mathrm{~mm}$, independently of the size of the body of the mouse, and in the oldest specimens - from 74 to $83 \mathrm{~mm}$. In general, the percentage relation of the length of the tail to that of the body in adult animals is greater in small individuals than in large ones.

The foot grows rapidly in length, attaining its final dimensions in individuals 5 months old. A considerable inhibition of growth takes place when the animals pass from the 2nd to the 3rd age group and soon accretion ceases entirely (Fig. 2). Young specimens (group III) were caught with feet as large as those of the biggest animals. The growth of the ear proved to be difficult to determine, as these measurements had not been carried out in the youngest specimens, and therefore they were incomplete in the older ones. However, data obtained from about 200 rodents indicate a process similar to that of the growth of the foot.

Weight is the element subject to the greatest changes in the course of development of mice. The percentage of weight accretion in the last age group amounts to 216.4, while the weight increases from 6 do $29.8 \mathrm{~g}$.

Weight increases the most rapidly in the youngest mice and it is inhibited in rodents of the IIIrd group. This is strictly connected with the period of development of these animals which takes place in autumn. In this case the difference between the rate of growth and the attaining of a suitable 
condition is the most apparent in animals of the first litters, as they are much heavier and bigger than mice from the later litters. The growth of these last ones is inhibited, as was already stated, and their weight diminishes considerably (Tables 2, 3). In relation to the month of September the mean weight of mice of the 3 rd group, caught in January diminishes by more than $3 \mathrm{~g}$, and $7 \mathrm{~g}$ in individuals of the 4 th group. A new increase of weight, proceeding by bounds, starts in the month of March (heavier individuals were even caught in February). A serious increase of weight takes place for a second time between May and June. This is probably caused by factors of a statistical nature rather than by the actual state of things (in May the weight of several individuals attained from $11.600 \mathrm{~g}$ to $20.100 \mathrm{~g}$ ). In the autumn and winter period the growth of all dimensions of the body is inhibited, and the weight decreases considerably. The average length of the body or of the tail seems to become shorter. This results from the fact that individuals from autumn litters, developing in much harder conditions, weighing less and having smaller dimensions of the body, pass into the older groups.

Correlation of age and weight is distinct in all age groups. Correlation with the length of the body is clearly apparent in young specimens (groups I, II, III) and diminishes slightly in older ones. The coeficicient of correlation $r_{x y}$ for specimens of the 2 nd group is equal to 0.748 , and to 0.534 for those of group V.

\section{CRANIOMETRICAL MEASUREMENTS}

The development of the visceral skull and of the brain-case in the period of growth of the field mouse has an irregular course. The Cb.-length is the taxonomic element most frequently used, its increase being regular (Fig. 3). A decrease of the accretion of this dimension, between groups IV and V is smaller by half when compared with the two first groups. This indicates a considerable inhibition of growth in the oldest individuals.

Table 4 illustrates the seasonal changes in $\mathrm{Cb}$. The increase of $\mathrm{Cb}$.length is suspended in the period from October to January, similarly as that in dimensions of the body and in its weight. A considerable increase in length is observed in March and April. The correlation with age is well developed in the youngest individuals and is much weaker in the oldest ones. The skulls of a relatively large percentage of animals of group III are no smaller than those of the oldest individuals. Correlation with the length of the body is considerable (for individuals of group $\mathrm{V} \mathrm{r}_{\mathrm{xy}}=0.703$ ). There exist however mice with a small length of body and a large skull or with inverse proportions.

The difference in dimensions of Cb.-length and of basal length of the 
Table 4.

Seasonal variability of $\mathrm{Cb}$.-length and of the nasal bone.

\begin{tabular}{|c|c|c|c|c|c|c|c|c|c|c|c|c|c|}
\hline Age & & 1 & II & III & IV & $v$ & $\begin{array}{l}M \circ \mathrm{B} \\
\mathrm{VI}\end{array}$ & $\begin{array}{c}t h s \\
\text { VII }\end{array}$ & VIII & $I X$ & $x$ & $x ?$ & XII \\
\hline II & $\begin{array}{l}\mathrm{Cb} \text {. } \\
\text { Nasal }\end{array}$ & & & & & 20.52 & 21.34 & $\begin{array}{r}19.63 \\
7.58\end{array}$ & $\begin{array}{r}19.01 \\
6.90\end{array}$ & $\begin{array}{r}19.41 \\
7.25\end{array}$ & $\begin{array}{r}20.10 \\
7.41\end{array}$ & $\begin{array}{r}20.71 \\
7.74\end{array}$ & \\
\hline III & $\begin{array}{l}\mathrm{Cb} . \\
\text { Nasal }\end{array}$ & $\begin{array}{r}21.16 \\
8.13\end{array}$ & & & & & & & $\begin{array}{r}21.35 \\
8.15\end{array}$ & $\begin{array}{r}20.89 \\
8.00\end{array}$ & $\begin{array}{r}21.13 \\
7.93\end{array}$ & $\begin{array}{r}21.07 \\
7.95\end{array}$ & $\begin{array}{r}21.16 \\
8.0 ?\end{array}$ \\
\hline IV & $\begin{array}{l}\mathrm{Cb} . \\
\text { Nasal }\end{array}$ & $\begin{array}{r}21.27 \\
7.96\end{array}$ & $\begin{array}{r}21.39 \\
8.19\end{array}$ & $\begin{array}{r}21.66 \\
8.26\end{array}$ & $\begin{array}{r}22.15 \\
8.43\end{array}$ & $\begin{array}{r}22.08 \\
8.34\end{array}$ & $\begin{array}{r}22.21 \\
8.61\end{array}$ & $\begin{array}{r}21.78 \\
8.32\end{array}$ & $\begin{array}{r}22.26 \\
8.61\end{array}$ & $\begin{array}{r}21.94 \\
8.29\end{array}$ & $\begin{array}{r}22.97 \\
8.68\end{array}$ & $\begin{array}{r}21.90 \\
8.42\end{array}$ & $\begin{array}{r}21.44 \\
8.12\end{array}$ \\
\hline $\mathrm{V}$ & $\begin{array}{l}\mathrm{Cb} . \\
\text { Nasal }\end{array}$ & & & & & $\begin{array}{r}22.68 \\
8.73\end{array}$ & $\begin{array}{r}22.77 \\
8.74\end{array}$ & $\begin{array}{r}23.19 \\
8.71\end{array}$ & & $\begin{array}{r}22.98 \\
8.57\end{array}$ & $\begin{array}{r}22.27 \\
8.28\end{array}$ & $\begin{array}{r}22.13 \\
8.38\end{array}$ & \\
\hline
\end{tabular}

Table 5.

Seasonal variability of height measured per and between the bullae, and of the capacity of the skull.

\begin{tabular}{|c|c|c|c|c|c|c|c|c|c|c|c|c|c|}
\hline \multirow{2}{*}{$\begin{array}{l}\text { Age } \\
\text { class }\end{array}$} & \multirow[b]{2}{*}{ Measurement } & \multicolumn{12}{|c|}{ Months } \\
\hline & & 1 & II & III & IV & $\mathbf{v}$ & VI & VII & VIII & IX & $x$ & XI & XII \\
\hline II & $\begin{array}{l}\text { Capac1ty } \\
\text { He1ght of skull } \\
\text { per bullas } \\
\text { Depth of } \\
\text { brain - oase }\end{array}$ & & & & & & & $\begin{array}{l}436 \\
8.4 \\
7.0\end{array}$ & $\begin{array}{l}441 \\
8.2 \\
7.0\end{array}$ & $\begin{array}{l}447 \\
8.1 \\
6.9\end{array}$ & $\begin{array}{l}468 \\
3.5 \\
7.0\end{array}$ & $\begin{array}{l}482 \\
8.4 \\
7.1\end{array}$ & \\
\hline III & $\begin{array}{l}\text { Capac1ty } \\
\text { He1ght of skull } \\
\text { per bullae } \\
\text { Depth of } \\
\text { bra1n - case }\end{array}$ & $\begin{array}{l}472 \\
8.2 \\
6.9\end{array}$ & & & & & & $\begin{array}{l}502 \\
8.9 \\
7.3\end{array}$ & $\begin{array}{l}530 \\
8.5 \\
7.2\end{array}$ & $\begin{array}{l}495 \\
8.5 \\
7.1\end{array}$ & $\begin{array}{l}506 \\
8.6 \\
7.2\end{array}$ & $\begin{array}{l}495 \\
8.6 \\
7.2\end{array}$ & $\begin{array}{l}491 \\
8.4 \\
7.1\end{array}$ \\
\hline IV & $\begin{array}{l}\text { Capao1ty } \\
\text { He1ght of skull } \\
\text { per bullao } \\
\text { Depth of } \\
\text { bra1n - case }\end{array}$ & $\begin{array}{l}484 \\
8.5 \\
7.1\end{array}$ & $\begin{array}{l}467 \\
8.3 \\
6.9\end{array}$ & $\begin{array}{l}483 \\
8.5 \\
7.0\end{array}$ & $\begin{array}{l}514 \\
8.7 \\
7.1\end{array}$ & $\begin{array}{l}493 \\
8.6 \\
7.3\end{array}$ & $\begin{array}{l}501 \\
8.7 \\
7.2\end{array}$ & $\begin{array}{l}510 \\
9.0 \\
7.4\end{array}$ & $\begin{array}{l}529 \\
8.7 \\
7.3\end{array}$ & $\begin{array}{l}509 \\
8.5 \\
7.2\end{array}$ & $\begin{array}{l}533 \\
8.7 \\
7.4\end{array}$ & $\begin{array}{l}499 \\
8.6 \\
7.3\end{array}$ & $\begin{array}{l}483 \\
8.6 \\
7.0\end{array}$ \\
\hline$\nabla$ & $\begin{array}{l}\text { Capaolty } \\
\text { He1ght of skull } \\
\text { per bullao } \\
\text { Depth of } \\
\text { braln - case }\end{array}$ & & $\begin{array}{l}495 \\
8.5 \\
6.9\end{array}$ & $\begin{array}{l}515 . \\
8.5 \\
7.2\end{array}$ & $\begin{array}{l}524 \\
8.7 \\
7.1\end{array}$ & $\begin{array}{l}509 \\
8.8 \\
7.3\end{array}$ & $\begin{array}{l}540 \\
8.9 \\
7.5\end{array}$ & $\begin{array}{l}521 \\
9.2 \\
7.6\end{array}$ & & $\begin{array}{l}537 \\
8.7 \\
7.5\end{array}$ & $\begin{array}{l}500 \\
8.8 \\
7.2\end{array}$ & $\begin{array}{l}540 \\
8.6 \\
7.5\end{array}$ & $\begin{array}{r}535 \\
8.6\end{array}$ \\
\hline
\end{tabular}

cranium is very exactly repeated in all groups, with the exception of group IV. There appears however an alteration in the proportion of the $\mathrm{Cb}$. and the entire length of the skull, its increase being much smaller (the difference between these dimensions is of $1.54 \mathrm{~mm}$ for mice of the $1 \mathrm{st}$ group, and only of $0.90 \mathrm{~mm}$. for those of group V). When the vaulting of the skull alters it provokes alterations of shape in the vicinity of the 
occiput near the foramen occipitale magnum. W a s i l e w s k i (1952) made the same observations in Clethrionomys glareolus ( $\mathrm{S} \mathrm{c} \mathrm{h} \mathrm{r} \mathrm{e} \mathrm{b} \mathrm{e} \mathrm{r} \mathrm{1780).}$

The nasal bone shows a considerable accretion. The process of its growth has an irregular course, with an increase of $16 \%$ for young animals of the 2nd group, while it diminishes down to $5.6 \%$ between groups IV and V. The entire accretion during independent life is of $37.9 \%$. The frontal bone grows much more slowly; its length is already considerable in the youngest mice. Great difficulties arose for determining its points of measurement, as the sutures between the nasal and the frontal bone have a complicated course. The increase of the frontal bone is more regular than that

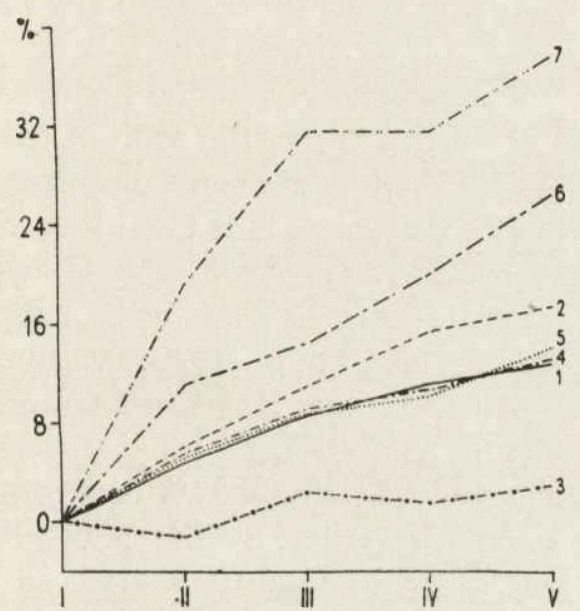

Fig. 3. Percentage of accretion in length of the skull.

1 - Occipital breadth, 2 - zygomatic breadth, 3 - interorbital constriction, 4 - depth of brain-case, 5 - height of skull per bullae, 6 - palatal depth, 7 brain-case capacity.

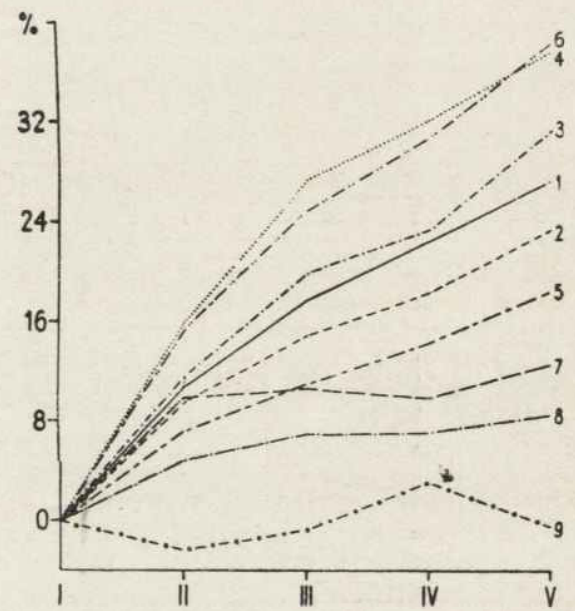

Fig. 4. Percentage of accretion of the skull in height and breadth.

1 - Cb.-length, 2 - general length, 3 basal length, 4 - nasal length, 5-diastema, 6 - length of the interparietal bone, 7 - Maxillary tooth-row length, 8 - length of the sut. sagittalis.

of the nasal bone (Fig. 3). This proves that in the process of aging the part taken by separate bones in the accretion of the skull is apt to change (the accretion of the nasal bone for mice from group II amounted to $1.01 \mathrm{~mm}$, and only $0.35 \mathrm{~mm}$ between group IV and V, while an analogous increase of the frontal bone attained 0.54 and $0.32 \mathrm{~mm}$ ). Two other elements of length show a very small or even a complete lack of accretion. The sagittal suture attains its maximal size in the youngest individuals and is not subject to any changes, but shows considerable individual variations. The oldest individuals often had dimensions smaller than the minimal ones of group I. An accretion was observed in the size of the interparietal bone, 
but only in individuals of the 1 st and 2 nd group. From this moment a complete inhibition of growth takes place. The diastema shows an accretion as considerable as that of the nasal bone and the proportion between them does not alter during the whole period of growth. The increase in length of the upper row of teeth is small, amounting to $8.7 \%$ in the oldest animals.

The increase of the skull in breadth is much slower and causes alterations of proportion in older individuals. Their cranium is relatively longer and more slender than that of young specimens. The breadth of the occipital bone alters but slightly, while the increase of the zygomatic processes is a little greater, but the breadth measured on the sutures of the zygomatic arcs increases in the greatest measure. With the advancing of age, the shape of the arcs is altered. They are bent downwards initially, but at a later period the curve diminishes considerably, and the arcs are disposed on a more horizontal plane. The breadth between the orbit of the eye shows a minimal increase as its size, in relation to the point of departure, increases only by $3 \%$. It can be assumed, therefore, that this breadth attains its maximal dimension in mice of group I. Og nev and Pryc hodk o (after W a s i le w s k i, 1952) are of the opinion that this breadth (in Clethrionomys glareolus) may diminish with age. I did not observe this in the field mouse. The accretion of growth, measured per bullae and between the bullae has a regular course, but is rather small (Fig. 4). The height of the palate, however, alters considerably, attaining $27 \%$ of accretion in very old specimens. The increase of the capacity of the skull is also intensive.

Seasonal variability in the dimensions of height and capacity of the skull is of interest. The phenomenon of a depression of the skull during winter, described by De h nel (1949) appears distinctly in insectivores. W a s ilew ski $(1952 ; 1956 ; 1960)$ cited a series of facts concerning regression in the Microtinae. As shown in the investigated material, this process also takes place in the Murinae. February is the critical month.

A diminishing of capacity of the brain-case of mice of the 4th group in February is of $8.4 \%$ in relation to that of group III in October, and that of the height measured over and between the bullae is of $3.6 \%$ and $4.35 \%$ (Table 5). All the skulls are very low. They can already be seen in autumn. In March the capacity and the height of the skull increases considerably. $\mathrm{W}$ a s i l e w s k i (1952) ascertained the largest dimensions in Bank voles, in individuals 2 months old. The mean figures for older animals were much lower. The increase of capacity in field mice has a more intensive course in the young, but is not completely inhibited in specimens which have lived through a winter. The same can be stated in connection with height dimensions. 


\section{INDICES}

The determining of indices is of great importance, as it furnishes a true possibility of comparing material studied by different authors. In certain cases suitably assorted indicators can form the only criterion for classification of the material into age groups. While the analysis presented above concerned alterations of absolute dimensions of the separate elements of body and skull in different aspects, the analysis of indices is related to the variations in the proportions of body and skull.

The index for body length/length of the tail (Table 6) demonstrates an alteration in the proportion of both these elements taking place with

Table 6 .

List of mean values for indices.

\begin{tabular}{|c|c|c|c|c|c|c|}
\hline \multirow{2}{*}{\multicolumn{2}{|c|}{ Index }} & \multicolumn{5}{|c|}{ Age class } \\
\hline & & I & II & III & IV & $\mathrm{v}$ \\
\hline 1. & $\frac{\text { Ta11 }}{\text { Head \& body }}$ & 78.3 & 85.2 & 86.3 & 82.8 & 78.5 \\
\hline 2. & $\frac{\text { Body we1ght }}{\text { Head \& body }}$ & 10.8 & 16.0 & 17.9 & 19.7 & 22.5 \\
\hline 3. & $\frac{\text { Condylobasal length }}{\text { Head } 2 \text { body }}$ & 26.6 & 25.5 & 25.9 & 24.1 & 22.6 \\
\hline 4. & $\frac{\text { Occ1p1tal breadth }}{\text { Condylobasal length }}$ & 52.8 & 50.0 & 48.6 & 47.8 & 46.5 \\
\hline 5. & $\frac{\text { Depth of bra1n-case }}{\text { Condylobasal length }}$ & 36.8 & 35.0 & 33.8 & 33.0 & 32.5 \\
\hline 6. & $\frac{\text { D1astema }}{\text { Condylobasal length }}$ & 26.7 & 28.0 & 28.4 & 28.7 & 29.0 \\
\hline 7. & $\frac{\text { Nasal lenght }}{\text { Condylobasal length }}$ & 34.9 & 37.2 & 38.5 & 38.3 & 38.1 \\
\hline 8. & $\frac{\text { Maxillary tooth-row }}{\text { Condylobasal length }}$ & 18.7 & 17.7 & 16.9 & 16.3 & 15.9 \\
\hline 9. & $\frac{\text { He1ght of skull per bullae }}{\text { Oco1p1tal bresdth }}$ & 69.7 & 70.0 & $69: 6$ & 69.0 & 69.7 \\
\hline 10. & $\frac{\text { Oco1pital breadth }}{\text { zygomat1g breadth }}$ & 91.5 & 90.4 & 87.9 & 84.6 & 83.5 \\
\hline
\end{tabular}

age. These changes are the most pronounced in mice of group III. The oldest individuals have the same proportions as the mice of the 1st age group. This is evidently connected with a difference in growth intensity of the tail and the body (Table 2). Individuals were captured for which this index amounted to 67.8 in long-tailed and 93.2 in short-tailed ones. When taking in consideration the very great extension of the index for individuals originating from the same territory and the same population, one can add that the present criteria forming the base for distinguishing 
subspecies are often disappointing, especially when the descriptions concern small material, undifferentiated as to age and season. The index for body length/weight shows a great individual variability also caused by age. This is connected with extremely great differences in the rate of development of both these elements. In old specimens the fluctuations of this index are in the limits of $17.8-29.8$, therefore in mice of the same age decidedly light and heavy individuals appear. These fluctuations are much lower, 9.5-13.5, in young animals.

The remaining indices are presented in Table 6. The indicators Cb.length/length of body, length of the upper teeth row/Cb., width of the occiput/ $\mathrm{Cb}$. and the height between the bullae/ $\mathrm{Cb}$. render visible the differences of proportions in young and old mice, caused in the first case by a more rapid increase of body length and in the following ones by a more intensive accretion of $\mathrm{Cb}$. The indexes diastema/Cb.-length; the length of the nasal bone/ $\mathrm{Cb}$. demonstrate a considerable increase in individuals of the 1st and 2nd group only. Later these proportions do not alter in principle. Constant proportions in mice of a different age are shown by the index of the height between the bullae/breadth of the occipital bone.

\section{SEX RATIO}

The material suggests possibility of investigating the numerical relation of both sexes. These problems are treated very carefully, as all the methods of collecting in use cannot possibly eliminate factors which render difficult an assessment of the state of things existing in nature. W a s ilewski(1952) is of the opinion that even a large material collected during a prolonged period, cannot allow to proclaim categorical inferences, the more so that the periods of mass capture of rodents, in spring and summer months (breeding period), play here a decisive role.

When operating with numbers, 242 $\%$ and $3020^{7} \sigma^{7}$ were caught, which corresponds to $44.5 \%$ and $55.5 \%$ of the entire material. The numerical relation of both sexes, investigated in age groups (Table 1) is not uniform. While in groups I, II and III numerical relation is in principle the same, in groups IV and V a distinct preponderance of males can be seen. This has a slightly different appearance in seasonal classification. Males prevailed decisively (1:2 as a rule) between February and August; in the remaining months the relation became equalised, with the exception of October, when nearly twice as many females were captured. In October a greater number of collected females is observed in all the groups, but their amount becomes equal in the next month, while in individuals of group IV males dominate. It is possible that this change is the result of increased mortality of young females in this period and during winter 


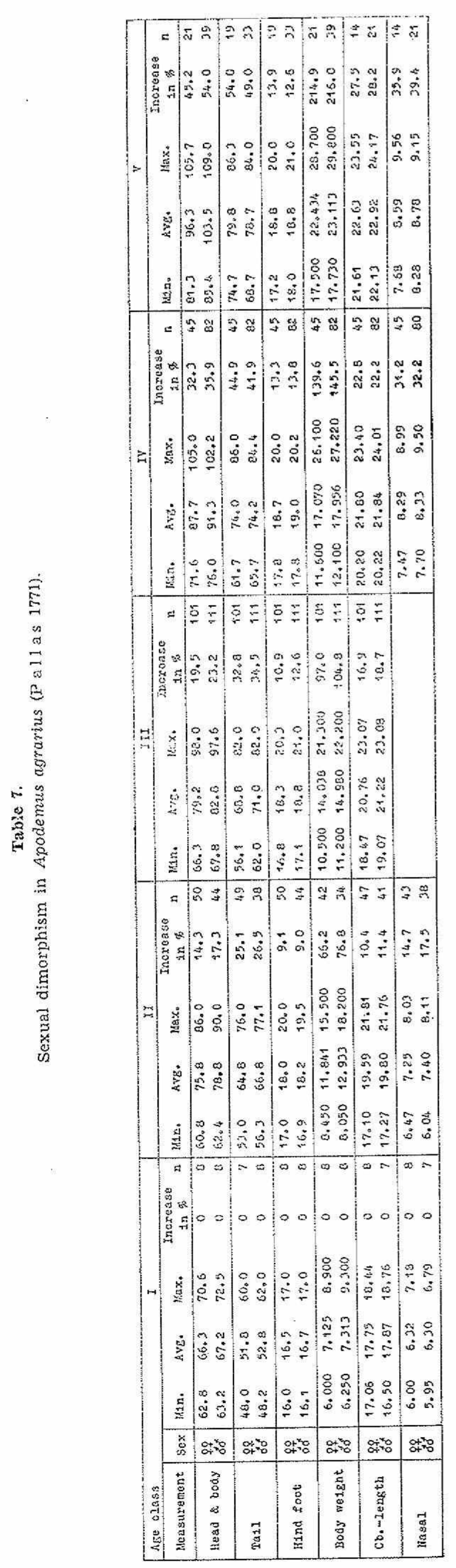



months, which in effect provokes a shifting of mutual numerical proportions. It also seems that females which have lived through a winter live longer than males; this is indicated by their presence in late autumn and winter months, when a complete absence of males is noted.

\section{SEXUAL DIMORPHISM}

Sexual dimorphism is distinctly marked in general dimensions of the body and in the weight, especially in old animals. The differences in mean figures for body length in the youngest individuals do not transgress $1 \mathrm{~mm}$, when the extension of dimensions is similar. In group II this difference between males and females attains $3 \mathrm{~mm}$, while in the oldest specimens it even surpasses $7 \mathrm{~mm}$. There occur, however, in the females individuals with dimensions surpassing $105 \mathrm{~mm}$ and which approach the maximal size for the investigated material. The males after leaving the nest have a more rapid increase of body length than the females. The equalisation of the increase rate in individuals of the two following groups is

\section{Table 8.}

Seasonal alterations of body length and of weight of females and males

\begin{tabular}{|l|l|l|l|l|l|l|l|}
\hline \multirow{2}{*}{ Measurement } & Sex & I & II & III & IV & V & VI \\
\hline \multirow{2}{*}{ Bead \& body } & If & 81.6 & 82.9 & 83.4 & 91.3 & 96.5 & 95.0 \\
& If & 84.4 & 87.0 & 91.8 & 96.8 & 98.0 & 97.8 \\
\hline \multirow{2}{*}{ Body we1ght } & of & 13.235 & 13.528 & 15.329 & 18.720 & 21.863 & 21.524 \\
& do & 13.556 & 19.248 & 19.110 & 20.491 & 22.780 & 22.021 \\
\hline
\end{tabular}

undoubtedly the result of an identical action of factors inhibiting growth in both sexes (the autumn and winter period). The increase in old animals is considerable, but its course is slower in females (8.6 and $12.2 \mathrm{~mm}$ ). Two periods of an intensive accretion of length become distinctly apparent, divided by a relatively long period of a slackened increase (Table 7). Augmentation of weight is also more intensive in young males; at a later period the difference in mean figures in separate weight groups does not surpass $1 \mathrm{~g}$. Material in seasonal classification shows that the increase of body length and of weight in old specimens has a different course for both sexes during late winter and in spring. When the length of the body and the weight of females in the month of January amounted to 81.6 and $13.335 \mathrm{~g}$ and to 84.4 and 13.566 (mean figures), in February the males were $87 \mathrm{~mm}$ long and weighed $15.248 \mathrm{~g}$, and the females $82.9 \mathrm{~mm}$ and 
$13.528 \mathrm{~g}$. Thus in the period when the dimensions and weight of females augmented insignificantly, the males attained a considerable increase (Table 8). This disproportion augments in the following month. In May and in later months this difference is considerably equalised in weight, but the disproportion as to the length of the body does not alter. It must be stated that sexual dimorphism is apparent, with a different intensity, in different seasons of the year.

The increase of the tail has an interesting aspect. In individuals of I-III age groups males have longer tails. But already in group IV the mean figures are equal. This proves that the growth of the female's tail at that time is much more rapid, especially increasing during the last period, while the growth of the tail of males is then slower. In relation with this fact, the index of body length/length of tail indicates clearly differences in the proportion of these elements in animals which have lived through a winter. Differences in the length of the foot and the ear could not be obtained.

It appeared in the previously discussed elements of the skull that a very great majority of bones do not differ as to dimensions and that mean figures calculated for separate age groups of both sexes were identical. Some rather weakly expressed differences appear exclusively in the general, basal and $\mathrm{Cb}$.-length and in the length of the nasal bone (Table 7). The greatest $\mathrm{Cb}$. differences appear in group III, attaining $0.5 \mathrm{~mm}$.; this relation is maintained in the same proportion for animals of group V. The highest $\mathrm{Cb}$. value in females amounts to $23.55 \mathrm{~mm}$. and $24.17 \mathrm{~mm}$. in males. The general and basal length show similar relations. Differences in the length of the nasal bone are of $0.2 \mathrm{~mm}$. in the oldest individuals.

As results from the given data, morphological differences in the skulls of field mice of both sexes, when compared with those presented by A d a mczewska (1960) for Apodemus flavicollis (M l chior 1834) are very insignificant and are, in principle, only limited to elements of the visceral skull and of $\mathrm{Cb}$. dimensions.

The colouring of adult specimens from Wrockaw in the late spring and summer period has a greyish-dark-rusty shade, of a dull hue, with a weak delimitation of colour on the sides and the hypogastrium. In relation of a very clear subspecies systematisation for Apodemus agrarius $(\mathrm{P}$ a 11 a s 1771) and a lack of comparable material, I consider that in the present phase it would not be advisable to formulate an opinion as to the subspecies appurtenance of the field mouse from the Wrocław area. 


\section{RESULT'S}

1. 544 specimens of Apodemus agrarius ( $\mathrm{P}$ a 11 a s 1771) collected in Wroclaw in the years 1959-1961 could be disposed of. The material was divided into 5 relatively easily differentiated age groups. Abrasion of the dentition was the criterion for division.

2. The age structure of a population is subject to constant and cyclic seasonal changes. Young individuals appear at the earliest in the month of May, and compose then only a small percentage of the population. This relation alters constantly during the summer. At the beginning of autumn the specimens that had lived through a winter die in great numbers. They are only sporadically captured in late autumn and in winter. Their life span in natural conditions does not transgresse $1^{1 / 2}$ year.

3. During their whole life an increase in separate dimensions of the body can be observed. It is inhibited in the autumn-winter period and intensified in spring. This is also the case in elements of the skull. The length of body, tail, foot and ear increase with special rapidity in young individuals (group I, II).

4. The percentage relation of the length of the tail to the length of the body in the youngest and the oldest specimens amounts to $78.5^{\circ} \%$ and is higher than that generally stated. In relation to the different intensity of growth of these elements, their proportions are also different in separate life periods.

5. The weight of the body is subject to the greatest alterations in the course of development. The percentage of accretion amounts to $216.4^{0} \%$. Mice from the first spring litters rapidly attain considerable dimensions and weight. Individuals born during the latter part of the summer and in autumn are much smaller on attaining the same age.

6. Elements of the visceral cranium increase intensively during the entire period of development. The bones of the brain-case attain adult dimensions already in young forms, or increase slightly in size. The increase of $\mathrm{Cb}$.-length is in the first place the result of the growth of the rostral part of the skull.

7. Measurements of the breadth and height of the skull show a slight increase. In relation to a much more rapid growth in length its proportions change with advancing age and the skull becomes more slender.

8. The phenomena of depression of the skull are weakly expressed. February is the critical month, although in certain cases depression may also be observed during autumn months.

9. Males prevailed in captured specimens, with the exception of autumn months. 302 males were caught and 242 females. Sexual dimorphism is weakly expressed. It appears mostly in the length of the body, and very slightly in other elements of the body and skull.

\section{REFERENCFS}

1. A d a m c z e w ska, A. K., 1959: Untersuchungen über die Variabilität der Gelbhalsmaus, Apodemus flavicollis flavicollis (M e $1 \mathrm{ch}$ i or 1834). Acta theriol., 3, 10: 141-190. Białowieża.

2. (A rg у r op u 1 о, А. І.) Агрыропульо, А. И., 1940: Млекопитающие СССР. Том 3: - Москва-Ленинград.

3. Borowski, S. \& Dehne 1, A., 1952: Materiały do biologii Soricidae. Ann. Univ. M. Curie-Skłodowska, C 7, 6: 305-448. Lublin. 
4. De hne 1, A., 1949: Badania nad rodzajem Sorex L. Ann. Univ. M. Curie-Skłodowska, C 4, 2: 17-102. Lublin.

5. E1l e rma n, J. R., 1949: The families and genera of living Rodents. British Mus. 3, 1: 1-120. London.

6. Kratochvil, J. \& Rosicky, B., 1954: K rozsireni a rozmnożovani mysice temnopase (Apodemus agrarius) v CSR. Zool, a entom. listy, 3(18), 2: 97-108.

7. Kubik, J., 1952: Badania nad morfologią i biologią smużki (Sicista betulina P a 11.) z Białowieskiego Parku Narodowego. Ann. Univ. M. Curie-Skłodowska, C 7, 1: 1-63. Lublin.

8. K u b ik, J., 1953: Micromys minutus P a 11. w Białowieskim Parku Narodowym. Ann. Univ. M. Curie-Skłodowska, C 7, 7: 449-495. Lublin.

9. (M е j e r, M. N.) Меер, М. Н., 1957: О возрастной изменчивости малого суслика (Citellus pygmaeus (Р a 11.).Зоол. журн., 35,9: 1393-1402. Москва.

10. Pucek, Z., 1955: Szybka metoda mierzenia pojemności czaszki drobnych ssaków. Wszechświat, 12: 308. Kraków.

11. Skuratowicz, W., 1948: Badania nad fauną ssaków Zamojszczyzny. Fragm. Faun. Mus. Zool. Pol., 5, 15: 233-292. Warszawa.

12. St e in, G., 1938: Biologische Studien an deutschen Kleinsäugern. Archiv f. Naturg., 7, 4: 477-513. Leipzig.

13. (V inogradov, B. S. \& Gromov, I. M.) Виноградов, Б. С. \& Громов, И. М. 1952: Грызуны фауны ССCP. А. Н. СССР: 1-297. Москва-Ленинград.

14. Wasilewski, W., 1952: Badania nad morfologią Clethrionomys glareolus glareolus $\mathrm{S} \mathrm{ch} \mathrm{reb.} \mathrm{Ann.} \mathrm{Univ.} \mathrm{M.} \mathrm{Curie-Skłodowska,} \mathrm{C} \mathrm{3:} \mathrm{119-211.} \mathrm{Lublin.}$

15. W a silewski, W., 1956: Untersuchungen über die morphologische Veränderlichkeit der Erdmaus (Microtus agrestis Li nn é). Univ. M. Curie-Skłodowska, C 9, 6: 261-305. Lublin.

-16. W a sile wski, W., 1960: Angaben zur Biologie und Morphologie der Kurzohrmaus, Pitymys subterraneus (de Selys - Long champs 1835). Acta theriol., 4, 12: 185-247. Białowieża.

College of Agriculture,

Chair of Zoology,

Wrocław, Cybulskiego 20.

\section{STRESZCZENIF:}

1. Dysponowano 544 okazami Apodemus agrarius (Pa 11 as 1771) zebranymi we Wrocławiu w latach 1959-1961. Materiał został podzielony na 5 stosunkowo latwo wyodrębniających się grup wiekowych. Jako kryterium podziału przyjęts stooień starcia uzębienia.

2. Struktura wiekowa populacji ulega stałym, cyklicznym zmianom sezonowym. Młode osobniki pojawiają się najwcześniej w maju i stanowią wówczas niewielki procent populacji. Stosunek ten ulega stałej zmianie w ciągu lata. Na początku jesieni przezimki intensywnie wymierają. Późną jesienią i zimą odławiane są wyłącznie sporadycznie. Długość życia w warunkach naturalnych nie przekracza $1^{1 / 2} \mathrm{roku}$ (tabela 1, Ryc. 1).

3. W ciągu całego życia obserwuje się przyrost poszczególnych wymiarów ciała. Ulega on zahamowaniu w okresie jesienno-zimowym, a intensyfikacji w czasie wiosny. Dotyczy to również elementów czaszki. Dlugość ciała, ogona, stopy i ucha zwiększa się szczególnie szybko u osobników młodych z I i II grupy (Tabela 2, Ryc. 2). 
4. Stosunek procentowy długości ogona do długości ciała u okazów najmłodszych ii najstarszych wynosi $78.5 \%$ i jest wiẹkszy od powszechnie podawanego. W związku z różną intensywnością wzrostu tych elementów, proporcje między nimi są różne w reoszczególnych okresach życia (Tabela 6).

5. Najwickszym zmianom w trakcie rozwoju ulega ciężar ciała. Procent przyrostu wwynosi 216,4. Myszy z pierwszych miotów wiosennych szyblko osiągają pokaźne rozmiary i wagę. Osobniki urodzone późnym latem i jesienią, w tym samym wieku są zznacznie mniejsze (Tabela 2,3).

6. Elementy trzewioczaszlki wzrastają intensywnie w ciągu całego okresu rozwojju. Kości mózgoczeszki osiagają cojrzałe rozmiary już u form młodocianych lub niezznacznie tylko potem wzrastają. Przyrost diugości $\mathrm{Cb}$. jest przede wszystkim wynilkiem wzrastania części rostralnej czaszki (Tabela 2, Ryc. 3).

7. Pomiary szerokościowe i wysokościowe czaszki wykazują niewielki przyrost. IW związku ze znacznie szybszym wzrostem na dlugość, proporcje czaszki ulegają zz wiekiem zmianie, czaszka staje się smuklejsza (Tabəla 2, Ryc. 4).

8. Zjawisko depresji czaszki jest slabo wyrażone. Miesiącem krytycznym jest luty. IW pewnym wypadkach zjawisko to można zaobserwować w miesiącach jesiennych ((Tabela 5).

9. W odlowach poza miesiącami jesiennymi przeważały samce. Złowiono ich 302 , ssamic 242. Dymorfizm płciowy jest na ogól słabo wyrażony. Szczególnie zaznacza się oon w długości ciała, nieznacznie w innych wymiarach ciała i czaszki (Tabela 1, 7).

\section{EXPLANATIONS OF PLATES}

\section{Plate LIII.}

Phot. 1-5. Abrasion of dentition in age groups $\mathrm{I}-\mathrm{V}$, respectively.

Plate LIV.

Phot. 6. Skull of an individual of the 1st age group.

Phot. 7. Skull of an individual of the 3 rd age group.

Phot. 8. Skull of an individual of the 5th age group.

FANSTWCWE WYDAWNICTWO NAUKOWE $\$$ WARSZAWA 1262

Naklad 1400 egz. Cbj. ark. wyd. 1,75. Maszynopis otrzymano 2.VI.1962. Podpisano do oruku 12.X: IF62. Druk ukoriczono 20.X.1962. Papier druk, sat. III 161., E0 g. Format E5. 
